\title{
The Analysis of N-Alkane Hydrocarbons in the Sediment Around the Coast of Makassar Using Mopi Indicator
}

\author{
MUHAMMAD Syahrir ${ }^{1, a}$, HASRI $^{1, b}$ and PINCE Salempa ${ }^{1, c}$ \\ ${ }^{1}$ Chemistry Department, Faculty of Mathematics and Natural Sciences, Universitas Negeri \\ Makassar, Indonesia \\ asyahrir_gassa@yahoo.com, 'bhasriu@unm.ac.id, 'pince.salempa57@gmail.com
}

Keywords: Analysis, n-alkanes, sediments, MOPI

\begin{abstract}
This study aims to determine the content of n-alkanes in the sediment around the coast of Makassar using the MOPI (Marine Oil Pollution Index) indicator. The method includes the sediment sampling from nine different stations with the Phleger Corer Sampler in gravimetric analysis to identify the concentration of organic material extract and aliphatic fraction. To identify the characteristic of n-alkane hydrocarbons, gas chromatography of mass spectra method was applied. The results of the aliphatic fraction $\left(\mathrm{F}_{1}\right)$ analysis of the coastal sediments which were contaminated with low biogenic - petrogenic have a MOPI scores of 3, which is supported by a high UCM (Unresolved Complex Mixture) and n-alkane identified between $\mathrm{C}_{1}-\mathrm{C}_{44}$. While the sediments that come from natural processes, pure - biogenic and biogenic, have MOPI scores between 1 and 2. This is supported by the chromatogram profile with an area of UCM generally smaller by n-alkanes identified between $\mathrm{C}_{15}-\mathrm{C}_{58}$.
\end{abstract}

\section{Introduction}

Indonesia consists of 17.500 islands with a coastline of more than $81,000 \mathrm{~km}$ and $70 \%$ of its population live in a coastal area $[17,18,24]$. In Eastern Indonesia, $90 \%$ of the area is highly potential sea to be developed and managed along with government policies which pay more attention to the field of marine exploration.

Coast in Indonesia, generally, are facing decay either in flux and reflux community or community of sea sediment, particularly around city center with oil production form offshore platform. It is estimated that about $35 \%$ of petroleum production in Indonesia derives from offshore oil wells. Petroleum sedimentation (such as n-alkane) and other natural resources occur happen since substantial hydrocarbon components in the sea do not dissolve and later are submerged in sediment [16]. The particles that make up marine sediments consist of 2 main origins, namely (1) formed from dissolved compounds (inorganic and especially organic) which are carried to the ocean as a solid phase and (2) scale from land or other places as a result of waste [13].

Data about the level of hydrocarbon oil pollution in the Makassar Strait waters is rarely obtained whereas such area is an important traffic for oil tankers from oil producers (Middle East) to their main consumers, Japan and North America. The pathway is an alternative to the Malacca Strait which has become a narrow but crowded sea lane, causing a lot of oil tanker collision [19].

Petroleum moves to the environment in the form of aliphatic or non-aliphatic hydrocarbons. These hydrocarbons are widely distributed throughout the ocean, atmosphere and land. The impact of petroleum in particular is the distribution of oil, especially those containing n-alkanes in marine sediments and causing severe pollution in certain places or on beaches.

It can be assumed that hydrocarbons in the marine environment are mainly from petroleum. Furthermore, petroleum in the form of aliphatic and aromatic hydrocarbons and organic acids in coastal areas and oceanic environments has the highest levels in the estuary and coastal regions [3, 14]. The presence of large amounts of petroleum spills in the sea as happened in March 1989 near Prince William Sound, Alaska (about 11 million gallons of oil) could cause severe damage to the marine ecosystem [8]. 
Petroleum entering the marine environment due to human activities, spreads relatively quickly through the physics process followed by chemical and biological processes. The spread of this oil will form layers that cover the surface of the sea and can last a long time and then gradually experience sedimentation or strand on the beach [23].

Oil sedimentation occurs because many petroleum components including normal alkanes that are insoluble in water form an emulsion with water so that it becomes heavy and drops to the seabed. The type and the distribution of normal alkane in the sediment are not yet identified.

According to Syahrir [25], the characterization of n-alkanes in the coastal sediments of LumuLumu Spermonde Island indicates the level of sea oil contamination based on MOPI has been contaminated with hydrocarbons from biogenic to moderate petrogenic. This is confirmed by the Molar Content (MC) indicator that some of the coastal area have been contaminated with petroleum hydrocarbons. However, the content and profile of n-alkanes along the Makassar Coast have not been identified. Based on the description above, it is interesting to examine the analysis of the n-alkane content in the sediments of Makassar coastal using the MOPI indicator.

\section{Reagents and Chemicals}

The research used chemicals such as standard PAH from Aldrich (Darmstadt) including Naphthalene, Pyrene, Fluoranthene, Phenanthrene, Acednapthene, Perylene, Benzo(a)Pyrene. Other chemicals were sodium sulfate anhydrate, silica gel 70-240 mesh, alumina at p.a quality from E. Merck, while helium, hydrogen and nitrogen were from Aneka Gas. Solvent n-hexane, dichloromethane with p.a quality was from E.Merck. Water used was aqua bidest from Pharmaceutical Lab.

Chemicals used in this research were glass equipment (Pyrex), rotary evaporator Buchii R II, vacuum pump (Hitachi, Ltd), sieve 1.00m no. 1 (Fisher Scientific Company), analytic balance A1.204 (Mettler Toledo), oven model 501 (Fisher), thermometer $\left(100^{\circ} \mathrm{C}\right)$ Hanna HI 314, hand refractometer, van Veen Grab, GPS (Global Positioning System) type Garmin 76 CSX, and gas chromatography detector FID from Shimadzu QP 2010.

\section{Eksperimental}

Sample used is sediment of Lae-lae island coast at Makassar, South Sulawesi at S $05^{\circ} 08.131^{\prime}$ ' and E119 $23.416^{\prime}$ using van Veen Grab. Sediment sample was wrapped with aluminum foil and taken to laboratory at room temperature.

Sample of 10 grams was extracted for 1 hour with solvent dichloromethane and n-hexane $(50: 50=\mathrm{v} / \mathrm{v}=1: 1)$ at $45^{\circ} \mathrm{C}[4,5]$. For resulted extract, its solvent is evaporated with rotary evaporator Buchii to obtain organic material extract at $45^{\circ} \mathrm{C}$ (EPA method 270). Separation of other organic material carried during extraction was done with clean-up. The clean-up used alumina with base characteristic. The alumina was processed as follows: \pm 200 gram alumina was extracted with dichloromethane in soxhlet for about 16 hours, then heated in oven at $200{ }^{\circ} \mathrm{C}$ for 8 hours and inactivated by adding aqua bidest (9-10\%) [16]. Distillation from clean-up process was separated using silica-gel - alumina (1:1) to obtain aliphatic and aromatic fractions. Aliphatic fraction containing n-alkane hydrocarbons was analyzed with GC-FID chromatography with external standard method. N-alkane hydrocarbons level in sediment is calculated using MOPI indicator following formula:

Notes:

$$
M O P I=\operatorname{Ln}\left[\frac{U C M_{h}}{R E S_{h}}+1\right]\left[\frac{\text { genap }+1}{\text { ganjil }}\right]\left[\frac{R A M_{F 1}+1}{n-\text { alkane total }}\right] R E S_{h}+U C M_{h}+U C M_{b}
$$

$\mathrm{UCM}_{\mathrm{H}} \quad=$ Unresolved complex mixture in alkane fraction in $\mathrm{mg} / \mathrm{kg}$ dry sediment

$\mathrm{RES}_{\mathrm{H}} \quad=$ Total resolved hydrocarbon in alkane fraction in $\mathrm{mg} / \mathrm{kg}$ dry sediment

GENAP $\quad=$ n-alkanes with even number in $\mathrm{mg} / \mathrm{kg}$ dry sediment

GANJIL = n-alkanes with odd number in $\mathrm{mg} / \mathrm{kg}$ dry sediment 
RAM F-1 = $=$ RES $_{H}$-total n-alkanes mass in $\mathrm{mg} / \mathrm{kg}$ dry sediment

$\mathrm{UCM}_{\mathrm{B}} \quad=\mathrm{UCM}$ in benzene fraction in $\mathrm{mg} / \mathrm{kg}$ dry sediment

Based on Figure V below, the MOPI scores were obtained in range between -2 and 15 representing the level of hydrocarbon contamination in marine sediments associated with the following conditions $[19,21,22]$ :

a. Index scores between -2 and 0 represent the level of hydrocarbon contamination in pure condition.

b. Index score in 2 represent the level of hydrocarbon contamination in biogenic condition.

c. Index scores between 3 and 5 represent the level of hydrocarbon contamination in biogenic to low petrogenic conditions

d. Index score in 6 represent the level of hydrocarbon contamination in low petrogenic to medium petrogenic.

e. Index scores between 7 and 9 represent the level of hydrocarbon contamination in medium petrogenic conditions

f. Index score in 10 represent the level of hydrocarbon contamination in medium petrogenic to high petrogenic.

g. Index scores between 11 and 14 represent the level of hydrocarbon contamination in high petrogenic conditions

h. Index scores which is more than 15 represent the level of hydrocarbon in highly progressive petrogenic condition.

\section{a. N-Alkane Analysis in Sediment Samples}

10 grams of dried sediment samples were sifted and put into a $250 \mathrm{ml}$ round bottom flask containing $100 \mathrm{ml}$ of dichomethane and $100 \mathrm{ml}$ of $\mathrm{n}$-hexane $(50: 50=\mathrm{V} / \mathrm{V}) \quad[5,6,7]$. The samples were extracted using Soxhlet for 18 hours, then cooled at room temperature [4]. The solvent was taken, filtered and evaporated using Buchii Rotary Evaporator at $45^{\circ} \mathrm{C}$. The samples were removed, filtered, and dried with sodium sulfate or glass wool then they were put into a small bottle and left until the temperature is cold (Organic Material Extract / EBO). The PAH fraction was separated from the aliphatic hydrocarbon fraction using clean-up and fractionation of the n-alkane fraction was analyzed by GC-MS.

\section{b. Analysis of Sediment Sample using GC-MS}

The experimental conditions of GC-MS used by using the type of Rtx-5 column are $30.0 \mathrm{~m}$ column length, $0.32 \mathrm{~mm}$ ID column diameter, maximum $330{ }^{\circ} \mathrm{C}$ column temperature, oven temperature: initial temperature $60,0^{\circ} \mathrm{C}$ and 1,00 minute hold time, reaching 36.5 minutes, rate of $8^{\circ} \mathrm{C} /$ minute with a temperature of $290,0^{\circ} \mathrm{C}$ and a hold time of 6.75 minutes, the type of detector FID with the condition of detector temperature $315^{\circ} \mathrm{C}$, He gas carrier $2-3 \mathrm{~mL} /$ minute, gas flow rate carrier 400 $\mathrm{mL} /$ minutes, $\mathrm{H}_{2}$ flow rate $35 \mathrm{~mL} / \mathrm{min}$ and air make up $30.0 \mathrm{~mL} /$ minute $[6,7]$.

\section{Result and Discussions}

\section{a. Gravimetric Analysis of N-Alkane Hydrocarbons in Makassar Coast Sediments}

Gravimetric results (Table 1) showed that EBO levels varied from 3342.67 to $21280.17 \mathrm{mg} / \mathrm{kg}$ dry sediments where station $4\left(\mathrm{AK}_{2}\right)$ was the lowest and station $1\left(\mathrm{JB}_{4}\right)$ was highest (Table 1$)$.

The results of hydrocarbon fractionation by chromatography column using silica gel: alumina (1: 1) and each sediment layer showed that the levels of aliphatic fractions containing various hydrocarbons. THK / EBO scores were varied and obtained (13.75 - 111.11)\%, the lowest at station $6\left(\mathrm{TR}_{2}\right)$ located near Makassar Transtudio Mall and the highest at station $5\left(\mathrm{TR}_{1}\right)$ which is also located near Makassar Transtudio Mall. This indicates that microorganism activity is high enough to degrade hydrocarbons in such stations area. 
Table 1. Results of gravimetric analysis of hydrocarbons in sediment ( $\mathrm{mg} / \mathrm{kg}$ dry sediment) (average score of two measurements)

\begin{tabular}{cccccccc}
\hline No & $\begin{array}{c}\text { Station } \\
\text { Code }\end{array}$ & $\begin{array}{c}\text { EBO (mg/Kg dr } \\
\text { sediment) }\end{array}$ & $\begin{array}{c}\text { F1 (mg/Kg } \\
\text { dry } \\
\text { sediment) }\end{array}$ & $\begin{array}{c}\text { F2 }(\mathrm{mg} / \mathrm{Kg} \\
\text { dry sediment })\end{array}$ & THK & $\begin{array}{c}\text { F1/ } \\
\text { F2 }\end{array}$ & $\begin{array}{c}\text { THK/ } \\
\text { EBO (\%) }\end{array}$ \\
\hline 1 & JB4 & 20262,47 & 4052,50 & 12157,48 & 16209,98 & 0,33 & 80,00 \\
2 & JB2 & 5570,92 & 3713,94 & 1237,98 & 4951,92 & 3,00 & 88,89 \\
3 & AK1 & 10688,37 & 7634,55 & 7634,55 & 15269,10 & 1,00 & 14,29 \\
4 & AK2 & 4149,91 & 5809,88 & 1659,96 & 7469,84 & 3,50 & 18,00 \\
5 & TR1 & 7239,86 & 4826,57 & 3217,72 & 8044,29 & 1,50 & 111,11 \\
6 & TR2 & 6871,10 & 6020,50 & 3440,29 & 9460,79 & 1,75 & 13,77 \\
7 & TL3 & 6184,21 & 6957,23 & 11595,39 & 18552,62 & 0,60 & 29,99 \\
8 & TL2 & 5946,64 & 2548,56 & 849,52 & 3398,08 & 3,00 & 57,14 \\
& Lae2/ & & & & & & \\
9 & Ktrl & 6020,50 & 928,55 & 371,41 & 1299,96 & 2,50 & 21,59 \\
\hline
\end{tabular}

\section{Notes:}

EBO : Organic Material Extract (mg/kg dry sediment)

F1 : Alkane Fraction ( $\mathrm{mg} / \mathrm{kg}$ dry sediment)

F2 : Aromatic Fraction (containing PAH) (mg/kg dry sediment)

THK : Total Hydrokarbon (mg/kg dry sediment)

F1/F2 : Comparison between Alkane Fraction and Aromatic Fraction

The result of the $F_{1} / F_{2}$ ratio (Table 1) also shows the varying scores of sediment sample at each station, between $(0.33-3.5)$, where the lowest hydrocarbon in sediment was at station $1\left(\mathrm{JB}_{4}\right)$ and the highest hydrocarbon in sediment was at station $4\left(\mathrm{AK}_{2}\right)$. Comparison of $\mathrm{F}_{1} / \mathrm{F}_{2}$ with scores obtained is less than 1 which indicates that hydrocarbons can be sourced from anthropogenic processes. So the station 1 sediment $\left(\mathrm{JB}_{4}\right)$ comes from anthropogenic processes while station 4 sediment $\left(\mathrm{AK}_{2}\right)$ is sourced from non-anthropogenic processes that can occur due to natural processes.

\section{b. Average Scores of MOPI from Each Stations}

MOPI scores have been calculated from several sediment samples from Makassar coast. Some chromatograms gas of sediment extract at each stations are shown as examples of stations contaminated with various biogenic and petroleum hydrocarbons derived from anthropogenic or pyrolytic sources. The relationship between hydrocarbon ratios and MOPI scores for these samples is displayed in Table 2 .

Table 2. Average of MOPI and categories of sediment stations from Makassar coast

\begin{tabular}{c|c|c|c}
\hline Station & Sample Code & MOPI Score & MOPI Descriptions \\
\hline $\mathbf{1}$ & $\mathrm{F}_{1} \mathrm{JB}_{4}$ & 2 & Biogenic \\
$\mathbf{2}$ & $\mathrm{F}_{1} \mathrm{JB}_{2}$ & 3 & biogenic-Low petrogenic \\
$\mathbf{3}$ & $\mathrm{F}_{1} \mathrm{AK}_{1}$ & 2 & Biogenic \\
$\mathbf{4}$ & $\mathrm{F}_{1} \mathrm{AK}_{2}$ & 3 & Biogenic - low petrogenic \\
$\mathbf{5}$ & $\mathrm{F}_{1} \mathrm{TR}_{1}$ & 3 & Biogenic - low petrogenic \\
$\mathbf{6}$ & $\mathrm{F}_{1} \mathrm{TR}_{2}$ & 3 & Biogenic - low petrogenic \\
$\mathbf{7}$ & $\mathrm{F}_{1} \mathrm{TL}_{2}$ & 1 & Pure - biogenic \\
$\mathbf{8}$ & $\mathrm{F}_{1} \mathrm{TL}_{3}$ & 3 & Biogenic -Low petrogenic \\
$\mathbf{9}$ & $\mathrm{F}_{1} \mathrm{Bsed}_{9}$ & 2 & Biogenic \\
& Mean & 2 & \\
\hline
\end{tabular}


Table 2 Shows that the MOPI scores of each station in the three sedimentary layers is in the range between 1 to 3 with the highest MOPI score is at station $8\left(\mathrm{~F}_{1} \mathrm{TL}_{3}\right)$ and the lowest is at station $9\left(\mathrm{~F}_{1}\right.$ Bsed9), with the average 2.41. This shows hydrocarbon contamination from pure to low petrogenic conditions.

The result at stations 2, 4, 5, 6 and 8 shows that the MOPI score is 3 of each with n-alkanes identified in $\mathrm{C}_{1}-\mathrm{C}_{44}$ showing the level of hydrocarbon contamination between biogenic and low petrogenic, which can be supported by the wide UCM clarifying that these hydrocarbons are in between biogenic and low petrogenic condition. This can be seen in the chromatogram profile and mass spectra from GC-MS analysis at station $8\left(\mathrm{~F}_{1} \mathrm{TL}_{3}\right)$. Ficture 1 and Ficture 2.
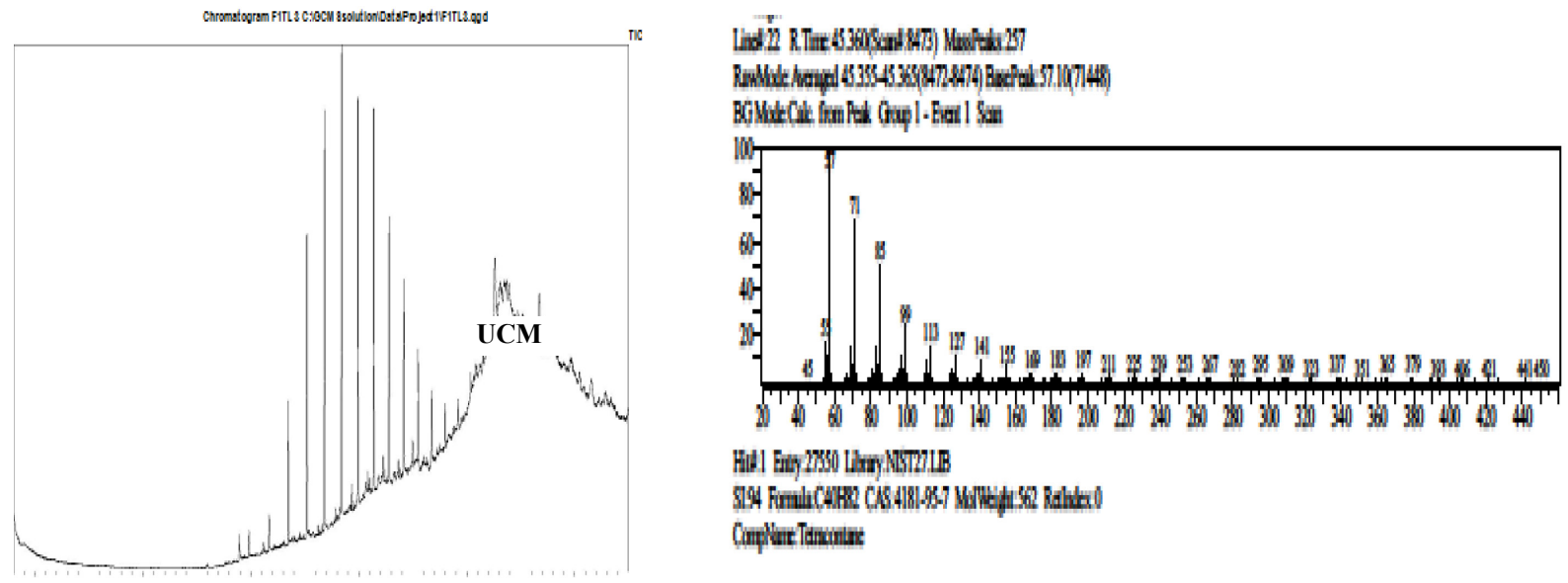

Picture 1. Sediment chromatogram profile of Picture 2. GC-MS Mass Spectra profile in Tello Station 8 from aliphatic fraction in Tello $3 \quad 3\left(\mathrm{~F}_{1} \mathrm{TL}_{3}\right)$ sediment sample, peaking at line 22 $\left(\mathrm{F}_{1} \mathrm{TL}_{3}\right)$ sediment sample

At stations 1 and 3, the score of the MOPI is 2 of each. This results in biogenic level of hydrocarbon contamination, which is supported by a wide low UCM (Unresolved Complex Mixture) indicating hydrocarbons derived from biogenic MOPI scores at station 7 and 9 are 1 and n-alkanes are identified in $\mathrm{C}_{13}-\mathrm{C}_{58}$. It indicates the level of hydrocarbon contamination are in between pure and biogenic, and supported by very low UCM area so that it is expected that around the station, microorganism activity will take place in many regions in this station. This can be seen in the chromatogram profile and mass spectra of the GC-MS analysis at station $8\left(\mathrm{~F}_{1} \mathrm{TL}_{3}\right)$. Figure 3 and Figure 4 below.
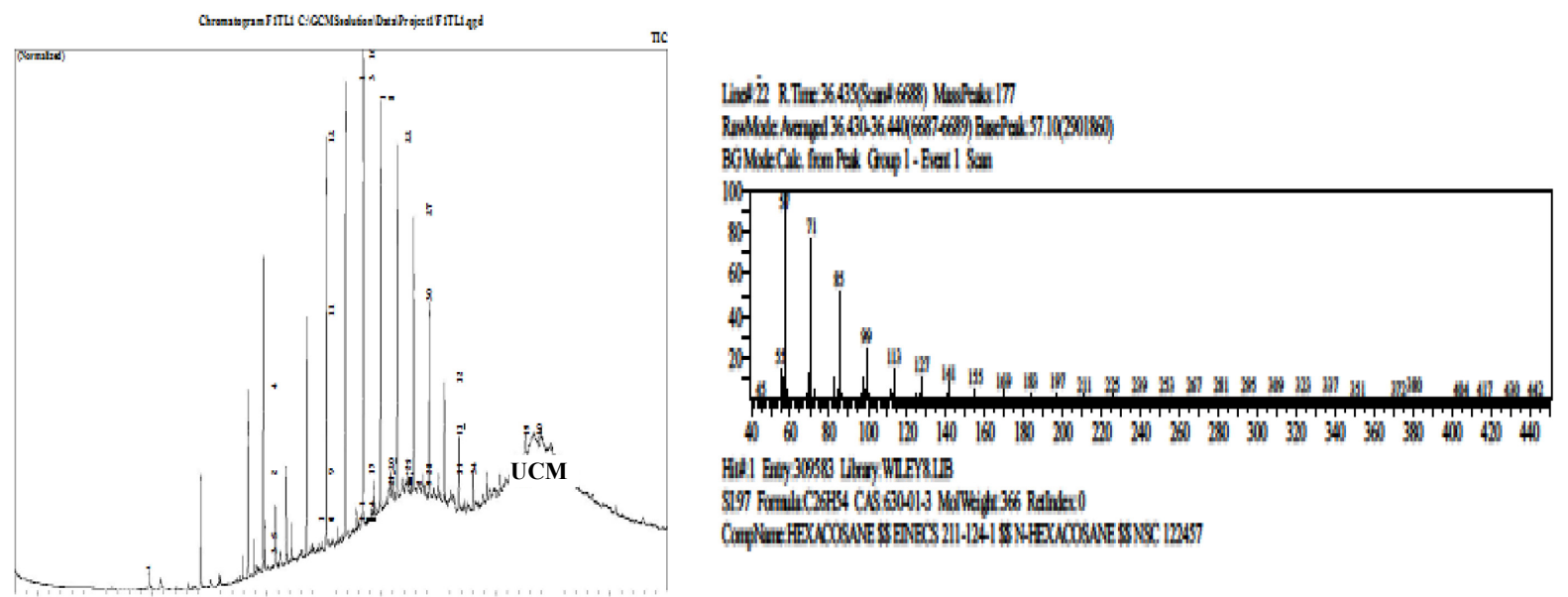

Picture 3. Sediment chromatogram profile at

Picture 4. GC-MS Mass Spectra profile in Tello station 8 from aliphatic fraction of Tello $23\left(\mathrm{~F}_{\mathrm{TL}}\right)$ sediment sample, line 22 as the lowest $\left(\mathrm{F}_{1} \mathrm{TL}_{1}\right)$ sediment sample 


\section{Conclusion}

The results of the aliphatic fraction (F1) analysis of the coastal sediments which were contaminated with low biogenic - petrogenic have a MOPI value of 3, which is supported by a high UCM (Unresolved Complex Mixture) and n-alkane identified between $\mathrm{C}_{1}-\mathrm{C}_{44}$. While the sediments that come from natural processes, namely pure - biogenic and biogenic, have MOPI values between 1 - 2 . This is supported by the chromatogram profile with an area of UCM generally smaller by n-alkanes identified between $\mathrm{C}_{15}-\mathrm{C}_{58}$.

\section{Acknowledgement}

We are very grateful for the completion of this research to Chemical Engineering Analytical Instrument Laboratory State Polytechnic of Ujung Pandang, especially Mr. Ahmad Rifai, S.Si., as the analyst in Laboratory of GC-MS, to the pary of Organic Chemistry Laboratory and Research Laboratory FMIPA UNM in carrying out preparation of research sample, and the donator of PNBP FMIPA UNM, and all of our partners in Chemistry Department of FMIPA UNM, who keeps giving contributions so that our research can run well and smooth.

\section{References}

[1] Benlahcen.K.T.et.al. 1997. Distribution and Sources of Polycyclic Aromatic Hydrocarbons in Some Mediterranean Coastal Sediments. Marine Pollution Bulletin. Vol. 34.No.5.pp.298-305.

[2] Canton, L., Grimalt, J.O., 1992. Gas chromatographic-mass spectrometric characterization of polycyclic aromatic hydrocarbon mixtures in polluted coastal sediments. Journal of Chromatography $607,279-286$.

[3] Clark, Jr.,R.C., 1974. Biological Fate of Petroleum Hydrcarbons in Aquatic Microorganism. Bacground Papers for Workshop on Inputs, Fates, and effects of Petroleum in The Marine Environment. Ocean Affairs Board, J. NAS, Washinton D.C., pp. 485 - 506.

[4] Elias Suhaimi, et.al. 2007. Polyciclic Aromatik Hydrocarbon (PAH) Contamination In The Sediments of East Coast Peninsular Malaysia. The Malaysian Journal of Analytical Sciences.Vol.11.No.1.: 70-75.

[5] Farrington, J.W., J.M. Tead, and P.L. Parker 1970. Petroleum Hydrocarbon. American Chemical Society, Washinton D.C.

[6] Golledge,W.R., dan Herzfelder, E.R., 2004. Method for the Determination of Extractable Petroleum Hydrocarbons (EPH). Depart. Environ. Protec. Revision 1.1.

[7] Golledge,W.R., dan Herzfelder, E.R.,2009. Method for the Determination of Extractable Petroleum Hydrocarbons (EPH). Depart. Environ. Protec. Revision 2.1.

[8] Hadi. S.N., 2003. Degradasi Minyak Bumi via Tangan Mikroorganisme. Diakses dari http: //www.chemistry.org/artikel_kimia/kimia_material/degradasi_minyak_bumi_via_tangan_mikroorga nisme.

[9] Hoffman, E.J., Mills, G.L., Latimer, J.S., Quinn, J.G., 1984. Urban runoff as a source of polycyclic aromatic hydrocarbons to coastal waters. Environmental Science and Technology 18, 580- 87.

[10] Jawahir, B. 1993. Studi Pencemaran Hidrokarbon di sekitar Pantai Desa Langnga (Selat Makassar) Kabupaten Pinrang Sulawesi Selatan. Tesis Program Pascasarjana Universitas Hasanuddin.

[11] LEMIGAS dan UNEXCO 1982. Occurrence of Tar Pollution Along Shore in Indonesia.

[12] Liu a,G.Q.et.al. 2005. Sedimentary record of Polycyclic aromatic hydrocarbons in a sediment Core from the Pearl River Estuary, South Cina. Marine Pollution Bulletin. 51 : 912 - 921. 
[13] Libel, M.S.,1992. An Introduction to Marine Biogeochemistry. John Wiley and Sons Inc. USA. [14] Mueller, J.G.,C.E. Cerniglia. \& P.H. Pritchard. 1996. Bioremediation of Environments Contaminated by Polycyclic Aromatic Hydrocarbons. Dalam: Crawford, R.I. and Crawford, D.I. (eds.). Bioremediation : Principles and Aplications. Cambrigde Univercity Press, Idaho. (hal.125128).

[15] Muhtar, M dan Razak, H. 1992. Statur Kemampuan Laboratorium P3O-LIPI Menganalisis Zat Organik Dengan Gas Khromatografi. Puslitbang Oseonologi-LIPI.

[16] National Academy of Sciences (NAS) 1975. Petroleum in the Marine Environment. Washington D.C.

[17] Nontji,A., 1997. Laut Nusantara. Cetakan Kedua. Penerbit Djambatan. Jakarta

[18] Nontji , A.,1999. Coral Reefs of Indonesia: Past, Present and Future. Proc. Lok. Pengelolaan \& Iptek Terumbu Karang Indonesia. Jakarta.

[19] Noor,A. 1988. Origine et Evoluiton des Hydrocarbons dans les Sediments Cotlers du Detroit de Makassar (Indonesia). Docteur en Science. Facultate des Sciences et. Tcultate des Sciences et. Techques de Saint-Jerome. De I'chques de Saint-Jerome. De I'Universite de Droit, d'Economoc et des Sciences d'Aix-Marseille,.

[20] Noor, A. and B. Jawahir. 1994. Hydrocarbon Profile in Coastal Sediment of Soutwest Sulawesi, Indonesia. Marine Science and Technology Bulletin, Vol. 5,5.

[21] Noor, A dan dan G. Mille 1988. Evolusi dan Dis Evolusi dan Distribusi n-alkana antara Dua Musim dalam Sedimen Permukaan Pantai Ujung Pandang. Laporan hasil penelitian Koperatif antara Universitas Hasanuddin-Indonesia dengan Universitas Aix-Marseille Perancis.

[22] Payne, J.R., J.R. Clayton Jr. C.R. Phillips, J.I. Lambach, and G.H. Farmer 1985. Marine Oil Pollution Index. Oil and Petrochemical Pollution, 2: 173-191.

[23] Pines et.al. 1981. Pines,A.Aronson.E., Kafry (1981). Burnout: From Tedium to Personal Growth, Free Press, New York.

[24] Sloan,N.A.,1993. Berbagai Dampak Minyak Terhadap Sumber Daya Laut Suatu Tinjauan Pustaka dari Seluruh Dunia yang Relevan Bagi Indonesia. Untuk Proyek Environmental Manajemen Indonesia dan Kantor Menteri Lingkungan Hidup.

[25] Sugiarto.E. 1999. Psikologi Pelayanan dalam Industri Jasa. Gramedia Pustaka Utama. Jakarta

[26] Syahrir.M.,2001. Karakterisasi n-Alkana dalam Sedimen Pantai Pulau Lumu-lumu Kepulauan Spermonde Melalui Indikator MOPI dan MC. Tesis Program Pascasarjana. Universitas Hasanuddin.

[27] Syahrir, M. 2013. Chromatogram Profile of PAH in EOM Before and After Fractionation of Dry-Wind Sediment From Kenjeran Coast Surabaya By Using GC-FID. Prosiding Seminar International FK UNM. 